\title{
Group work training program to develop social workers' knowledge of creative methods in maintaining elderly people's life quality
}

\section{Mahmoud M. Mounier Ph.D.}

Associate Professor of Social Group Work,

The Higher Institution of Social Work, Alexandria 


\begin{tabular}{||lr|}
\hline $\begin{array}{l}\text { The Egyptian Journal of Social Work (EJSW) } \\
\text { ISSN: } 2356-9204\end{array}$ & www.ejsw.org \\
Vol 1, No.5, January 2018
\end{tabular}

\title{
Group work training program to develop social workers' knowledge of creative methods in maintaining elderly people's life quality
} Mahmoud M. Mounier Ph.D.

Associate Professor of Social Group Work, The Higher Institution of Social Work, Alexandria

\begin{abstract}
:
The purpose of this study was to determine the effectiveness of the group work training program to develop social workers' knowledge of creative methods in maintaining elderly people's life quality. Eighteen social workers were assigned as one group pre- posttest design, (intentional sample from social workers at the association) working at the social care association in Karmouz, Alexandria which has twenty four residents. The 18 social workers were asked to complete three forms of measurement (pre, post and following). Firstly, a measurement was used to assess the social workers' knowledge of the creative methods to maintain elderly people's life quality. Secondly, the observation form assessed the changes in residents at the elderly care home during the experiment. The social workers in the experimental group were introduced to the group work training program to develop their knowledge of creative methods in maintaining elderly people's life quality. The intervention lasted for 15 weeks. The results emphasise the success of the group work training program to develop social workers' knowledge of creative methods in maintaining elderly people's life quality
\end{abstract}

Keywords: group work- training program - creative methods - elderly people's life quality.

\section{Introduction:}

The study seeks to determine the effectiveness of the group work training program to develop social workers' knowledge of creative methods in maintaining elderly people's life quality. This could be achieved through three sub purposes:

1. Develop social workers' awareness of old age.

2. Develop social workers' knowledge of creative methods in maintaining elderly people's life quality.

3. Support social workers in using creative methods to maintain elderly people's life quality. 


\section{The Egyptian Journal of Social Work (EJSW) www.eisw.org \\ ISSN: 2356-9204 Vol 1, No.5, January 2018}

The research idea came from an increased interest in the elderly people of Egypt, stemming from an increase in their numbers, as the Central Agency for Mobilization and Statistics reported in 2015 that statistical indicators related to the elderly (60 years and more) reached $6.9 \%$ of the total population in Egypt, this equates to 6 million people, 3 million males and 3 million females. This number is expected to rise to $11.5 \%$ in 2031 . In addition, there has been a decline in the number of elderly care homes, from 170 in 2014 to 168 in 2015, while the number of beneficiaries has increased from 3180 to 3961, according to the latest statement of the Social Services report in 2015.(The Central Agency for Mobilization and Statistics, 2015).

the statistical book mentioned that the number of the elderly was 1325 distributed at the elderly homes in Alexandria governorate, which is 23 elderly homes, some of them belong to the governorate sector, the other belong to NGOs and private sector. The number of social workers who work in it is 141 . Beside the nutrition supervisors, night supervisors, nurses, psychologists and doctors. The social care association in Karmouz has been selected according to the availabilities of a set of standards which are the association's cooperation with the researcher and agreed to implement the experiment, provide materials and resources to help in using creative methods with the elderly groups, the availability of the largest number of social workers graduated from social work to conduct the experiment and the similarity between them. (The Central Agency for Mobilization and Statistics, 2016).

This Increased interest about elderly people is concomitant with cultural and living developments, as well as the abandonment of some younger people in caring for one or both of their parents. This could be as a result of social pressure, working conditions and high cost of living, which has forced younger people to make the decision to put their parents into elderly care homes. Also Egypt's growing need for care and treatment for the elderly requires appropriate policies to deal with it. The lack of these policies leads to significant cost increases; therefore, health promotion and enhancement programs are encouraging people to monitor their health. The International Conference on Population and Development ICPD set goals in 1994 to increase people's healthy years, improve quality of life, reduce mortality and increase life expectancy. These objectives can be achieved effectively by implementing the procedures to improve 


\section{The Egyptian Journal of Social Work (EJSW) www.ejsw.org \\ ISSN: 2356-9204 Vol 1, No.5, January 2018}

public health, as recommended by the World Health Organization (WHO).

Researchers seek to write an article about methods which the specialists can used with the elderly such as drawing or sculpture, listening to quiet music, using a musical instrument, listening to songs and telling a story or memory, can be used in a group to help restore memories from the past. The aim is to work with the elderly, enabling elderly people to assert themselves. Social workers can be trained to use creative methods with elderly groups, helping them to participate in activities through a program which is appropriate for their skills. The program must activate the various senses; ensure willing participation from the elderly person, take place at an appropriate time, and have a responsible leader for each group, who is, in turn, supervised by a social worker. (Heba Mohamed Tawfik, 2012).

In addition, there are numerous studies focused on the creative methods used in social work, such as the historical relationship between art therapy and social group work, which has been examined through poetry writing groups for the elderly. The skills used in these groups are delineated and examples of poetry are analyzed. The intrinsic value of elderly people's poetry is emphasized over an instrumental view of arts as media.(George S Getzel, 2008, PP 65-76).

So, there is a need for more succinct assessment, particularly where a substantial expected change in health and quality life for the elderly people. This evaluation must conduct continuously in elder people homes to know their needs, what they able to do and their skills (K. L. Haywood Email, A. M. Garratt, R. Fitzpatrick, 2005, pp. 1651-1668).

Geriatric rehabilitation includes medical treatment, physical therapy, and therapy in both the psychosocial field and the activities of daily living (ADL). Its objective is to return the individual to independent functioning. This may be achieved through art therapy, which enables verbal and non-verbal communication; the expression of personal feelings; and physical, sensorimotor, and cognitive therapy. Group work with hospitalized elderly people is generally limited, especially art therapy using clay. Yet it can stimulate feelings of fellowship and evoke a sense of cooperation and support. (Yaretzky A , Levinson M, Kimchi OL, 1996).

In order to discuss maintaining the quality of life for the elderly in one study (David Banister, Ann Bowling,2004, p.p105-115).), the concept of quality of life is Simplify in order to better understand what 


\section{The Egyptian Journal of Social Work (EJSW) www.ejsw.org \\ ISSN: 2356-9204 Vol 1, No.5, January 2018}

older people say about the quality of life. They focus on the transport dimension where quality of life is distributed into mobility patterns, locality and social networks. This was a summary of secondary data and collected from 1000 elderly people as part of the British Office for National Statistics Omnibus Surveys in Britain.

Quality of life is described often with both objective and subjective dimensions. The majority of elderly people evaluate their quality of life positively on the basis of social contacts, dependency, health, material circumstances and social comparisons. Adaptation and resilience might play a part in maintaining good quality of life. Although there are no cultural differences in the subjective dimension of quality of life, in the objective dimension differences do exist. Two major factors to be considered with regard to quality of life in old age are dementia and depression (Gopalakrishnan Netuveli, David Blane, 2008, pp. 113-126). Another study's findings (Karen la Cour,2009) suggests that the domain of creative activity can enable the creation of connections to daily life, and enlarge the experience of self as an active person, in the face of uncertain life-threatening illness. Ultimately, the features that participants specify can be used to refine and substantiate the use of creative activities in intervention and general healthcare.

Social work encourages creative ways of working to resolve the challenges vulnerable people face and aims to promote empowerment, enabling people to take action to improve their lives. The profession works with people in a variety of different ways appropriate to individual circumstances, to help them achieve independence and exercise their human and rights. (Simeon Brody, 2010)

This study is different from previous studies because it focuses on training social workers based in elderly care homes, to use creative methods with elderly groups trying to maintain the quality of life that elderly people were used before entering the elderly care home, and not to raise the standard of life, may appear simple but represents creativity in the elderly. Through seminars about old fashions, showing some clothes so the colors and textures can be enjoyed, revitalizing the senses and restoring memories. Flowers are also an interesting subject for elderly people to focus on. Memories about different seasons of the year, rain, writing poetry, coloring, paper recycling, use of clay in the work of technical forms to strengthen hand muscles, making cards for birthdays and religious events, playing games. All these activities can be used to maintain quality of 


\section{The Egyptian Journal of Social Work (EJSW) www.ejsw.org \\ ISSN: 2356-9204 \\ Vol 1, No.5, January 2018}

life for the elderly. That's what the findings emphasize of the experiment yielded positive results related from the group work training program to develop social workers' knowledge of creative methods in maintaining elderly people's life quality.

\section{Methodology:}

Hypothesis: The main hypothesis for the present study was to explore whether or not there was a positive result in using a group work training program to develop social workers' knowledge of creative methods in maintaining elderly people's life quality.

\section{Sub hypotheses:}

1. There is a positive result in using a group work training program to develop social workers' awareness around older age and maintaining elderly people's life quality.

2. There is a positive result in using a group work training program to develop social workers' knowledge of creative methods used to maintain elderly people's life quality.

3 . There is a positive result in using a group work training program to support social workers' in using creative methods to maintain elderly people's life quality.

Participants: The present study assigned as one group prepost-test design, selected an intentional sample of social workers at the social care association, Karmouz, (18 social workers), because the association refused to exclude any of social worker to attend the training program, so the researcher applied three measures (prefollow-post) for social workers.

The results were compared to the main study's problem which is train the social workers to use creative methods for maintain the elderly quality life in the elderly home, considering to the improvement or decrease as an indicator which is a judge to the program' success instead of using the control group. Therefore, none of the social workers were excluded to achieve the public benefit. 


\begin{tabular}{||ll||}
\hline $\begin{array}{l}\text { The Egyptian Journal of Social Work (EJSW) } \\
\text { ISSN: 2356-9204 }\end{array}$ & Www.ejsw.org \\
Vol 1, No.5, January 2018 \\
\hline
\end{tabular}

There are many elderly homes at Alexandria governorate:

\begin{tabular}{|c|c|c|c|c|}
\hline \# & $\begin{array}{l}\text { The name of the } \\
\text { elderly care }\end{array}$ & $\begin{array}{c}\text { The NGO - } \\
\text { governorate sector- } \\
\text { private sector }\end{array}$ & $\begin{array}{c}\text { No of } \\
\text { social } \\
\text { worker }\end{array}$ & $\begin{array}{l}\text { No of } \\
\text { elderly } \\
\text { people }\end{array}$ \\
\hline 1 & Elwedad elderly care & $\begin{array}{l}\text { social care association in } \\
\text { Karmouz }\end{array}$ & 18 & 24 \\
\hline 3 & El shikh elderly care & Vatican NGO & 6 & 45 \\
\hline 4 & $\begin{array}{l}\text { The German elderly } \\
\text { care }\end{array}$ & Vatican NGO & 5 & 65 \\
\hline 5 & San Franswa elderly care & Vatican NGO & 7 & 48 \\
\hline 6 & $\begin{array}{l}\text { The Italian elderly } \\
\text { care }\end{array}$ & Italian charity $\mathrm{NGO}$ & 9 & 54 \\
\hline 7 & Antoniadis & Greek NGO & 4 & 33 \\
\hline 8 & $\begin{array}{l}\text { Elhanaa for elderly } \\
\text { care }\end{array}$ & Red Crescent NGO & 3 & 38 \\
\hline 9 & Elhanaa for elderly care & Red Crescent NGO & 4 & 31 \\
\hline 10 & $\begin{array}{l}\text { Happiness for elderly } \\
\text { care }\end{array}$ & $\begin{array}{l}\text { The public Ngo for } \\
\text { elderly care }\end{array}$ & 5 & 55 \\
\hline 11 & $\begin{array}{l}\text { Mohamed Ragab for } \\
\text { elderly care }\end{array}$ & Red Crescent NGO & 3 & 49 \\
\hline 12 & $\begin{array}{l}\text { Family tenderness for } \\
\text { elderly care }\end{array}$ & Mostafa Kamel NGO & 6 & 51 \\
\hline 13 & $\begin{array}{l}\text { Ahmos Khalifa for } \\
\text { elderly }\end{array}$ & $\begin{array}{lll}\begin{array}{l}\text { Alexandria } \\
\text { elderly care }\end{array} & & \\
\end{array}$ & 11 & 152 \\
\hline 14 & "Holy Family House & Vatican NGO & 7 & 78 \\
\hline 15 & Om elnour for elderly & Friends of the Bible Ngo & 6 & 83 \\
\hline 16 & Elhadaya for elderly & Social Defense NGO & 8 & 79 \\
\hline 17 & Elhadaya for elderly & Social Defense NGO & 7 & 19 \\
\hline 18 & $\begin{array}{l}\text { Christian Brotherhood } \\
\text { for elderly care }\end{array}$ & Christian Brotherhood NGO & 6 & 84 \\
\hline 19 & $\begin{array}{l}\text { The beautiful time for } \\
\text { elderly }\end{array}$ & $\begin{array}{l}\text { Girls of Light and } \\
\text { Community Development }\end{array}$ & 5 & 57 \\
\hline 20 & $\begin{array}{l}\text { The golden Age for } \\
\text { elderly }\end{array}$ & $\begin{array}{l}\text { Women Association for } \\
\text { Health Improvement }\end{array}$ & 5 & 43 \\
\hline 21 & $\begin{array}{l}\text { Almohdeen for } \\
\text { elderly }\end{array}$ & $\begin{array}{l}\text { Almohdeen } \\
\text { community } \\
\text { development }\end{array}$ & 4 & 53 \\
\hline 22 & $\begin{array}{l}\text { The beautiful time for } \\
\text { elderly }\end{array}$ & $\begin{array}{l}\text { Girls of Light and } \\
\text { Community Development }\end{array}$ & 6 & 68 \\
\hline 23 & $\begin{array}{l}\text { Almwasaa for elderly } \\
\text { care }\end{array}$ & Almwasa NGO & 6 & 56 \\
\hline \multicolumn{3}{|c|}{ Total } & 141 & 1325 \\
\hline
\end{tabular}




\section{The Egyptian Journal of Social Work (EJSW) www.ejsw.org \\ ISSN: 2356-9204 Vol 1, No.5, January 2018}

Justification of the social care association - Karmouz:

- Cooperation of association mangers with the researcher and welcome to implement the experiment.

- Provide resources helping in use of creative means with groups of the elderly

- The availability of an appropriate number of social workers graduated from social work institutes to conduct the experiment and somewhat the similarity in knowledge. The other associations have a larger number of night supervisors and supervisors of nursing, nutrition and doctors without regard to the specialization of social work and its importance within associations.

Figure no (1) shown the Social workers' data at Karmouz association:

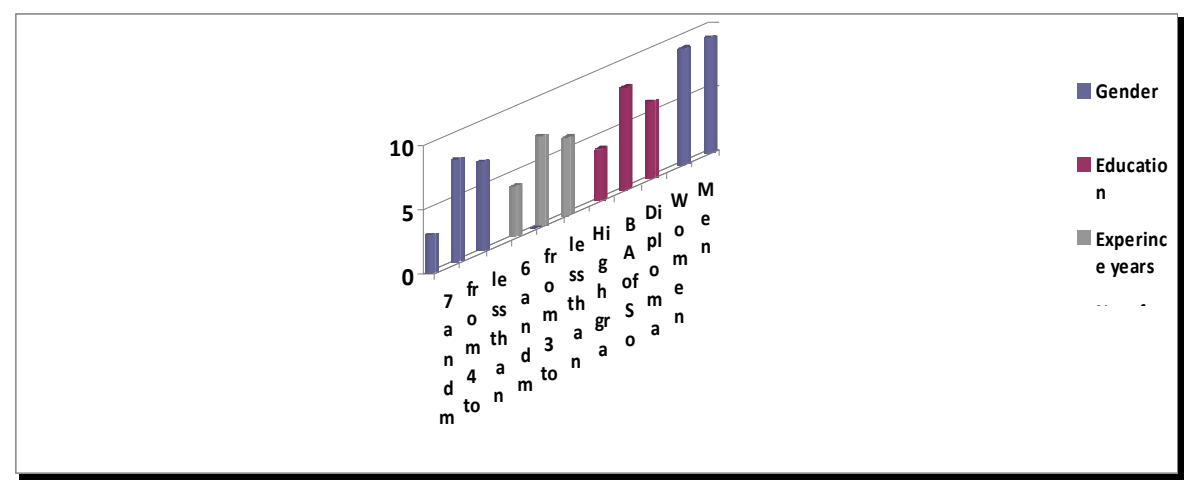

Procedures: The present study applied a training program for social workers to develop their knowledge of creative methods to maintain elderly people's life quality at the social care association, Karmouz, (the social workers did not already use creative methods in dealing with elderly people at the association). Depending on the group work's settings in the training program, firstly the researcher applied the pre measure on the social workers and elderly people at the association. Then tasks were distributed between social workers, who divided the elderly people into small groups, and applied their new-found knowledge and creative methods, which they gained from the training program. Then the post measure was applied to the social workers and elderly people, and the intervention stopped. After 4 weeks, the researcher visited the elderly care home and applied the following measure on the social workers, which showed up the changes that occurred to the elderly groups, through applying the observation tool to 24 elderly people. 


\section{The Egyptian Journal of Social Work (EJSW) www.eisw.org \\ ISSN: 2356-9204 Vol 1, No.5, January 2018}

Intervention: The training program ran for 16 weeks (from Feb 2017 to the middle of May 2017). The group meetings were held once a week for 2 to 2.5 hours. The first three weeks of the program's meetings were to develop social workers' awareness around older age, and how to maintain elderly people's life quality by defining the concept of the elderly, types and discussing issues about the elderly, including characteristics and problems faced by elderly people. In addition to group discussion with social workers about these areas, social workers were also assigned tasks to research these facts before meetings, and every social worker presented a paper to discuss with his colleagues. Finally, the researcher commented on these discussions with help from a doctor specialized in the geriatrics. From the fourth to the eighth weeks of the training program, meetings focused on developing social workers' knowledge of the creative methods used to maintain elderly people's life quality. (See supplementary material, table no 7) This segment of the training included the following: how the elderly enjoy life at the association, how to use art, painting, or sculpture to help them to imagine the past and memories, and how to use creative methods (music, pottery, sport ...). In addition, providing all the abilities at the association, from lighting and ventilation, to help the elderly feel dignified and able to maintain their life quality. The meetings during the ninth, tenth and eleventh weeks focused on supporting social workers to use creative methods in maintaining elderly people's life quality, and give the social workers time after every meeting to apply and report all the creative activities conducted with his elderly group. Social workers then presented their reports in the next meeting to discuss them with colleagues, answer all questions and present the obstacles which faced him in application. In the last four weeks, the researcher visited the association to monitor the work inside, without any interference in the social workers' work, and to report all the results from the intervention. The researcher applied the measurement to the social workers' work with the elderly as a following (the third time), and reported all the changes through the observation tool which was applied to the elderly people three times in order to report the changes after every stage from the intervention (pre, post and following). Finally, a small party was held for all the elderly people, social workers and others at the end of the training program. 


\section{The Egyptian Journal of Social Work (EJSW) www.ejsw.org \\ ISSN: 2356-9204 \\ Vol 1, No.5, January 2018}

\section{Measures:}

The measurement of the group work training program to develop social workers' knowledge of creative methods in maintaining elderly people's life quality, has 3 components as shown below. The first component, comprising 25 items, is developing social workers' awareness around older age. The second component was about developing social workers' knowledge of creative methods used to maintain elderly people's life quality. The third component, comprising 30 items, was about supporting social workers in using creative methods to maintain elderly people's life quality. The measurement used a Likert Scale. The scale included the following options: Agree $=3$; Almost agree $=2$; and Not agree $=1$. The measurement was re-tested after 15 days.

Table 1: The values of consistency and reliability coefficients for social workers of the components of the measurement-:

\begin{tabular}{|c|c|c|c|c|}
\hline 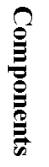 & Measurement's component & $\begin{array}{l}\text { Cronbach's } \\
\text { Alpha }\end{array}$ & $\begin{array}{c}\text { Standardized } \\
\text { Cronbach's Alpha }\end{array}$ & Validity \\
\hline 1 & $\begin{array}{l}\text { Develop sawareness around 'ocial workers } \\
\text { s life'er age and maintaining elderly peopleold } \\
\text { quality }\end{array}$ & 0.949 & 0.950 & 0.901 \\
\hline 2 & $\begin{array}{l}\text { Develop social worker' knowledge of creative } \\
\text { methods to maintain elderly people's life } \\
\text { quality }\end{array}$ & 0.945 & 0.943 & 0.893 \\
\hline 3 & $\begin{array}{l}\text { Support social workers in using creative } \\
\text { methods to maintain elderly people's life } \\
\text { quality }\end{array}$ & 0.938 & 0.934 & 0.880 \\
\hline
\end{tabular}

Source: the measurement collected from the research sample.

The observation tool of the elderly, which observed the changes that happened as a result of the training program conducted with social workers, has 29 items and it is divided into a Likert Scale. The scale was as follows: $($ Always $)=3$; $($ Sometimes $)=2 ;($ Never $)=1$. The observation tool was applied on all the elderly people at the elderly care home in the social care association, then the observation tool was re-tested after 15 days. 


\begin{tabular}{||lr||}
\hline The Egyptian Journal of Social Work (EJSW) & Www.ejsw.org \\
ISSN: $2356-9204$ & Vol 1, No.5, January 2018 \\
\hline
\end{tabular}

Table 2: The values of consistency and reliability coefficients for the observation tool of the elderly:

\begin{tabular}{|c||c||c||l||c||}
\hline \hline Component & $\begin{array}{l}\text { Measurement 's } \\
\text { component }\end{array}$ & $\begin{array}{l}\text { Cronbach's } \\
\text { Alpha }\end{array}$ & $\begin{array}{l}\text { Standardized } \\
\text { Cronbach's } \\
\text { Alpha }\end{array}$ & Validity \\
\hline \hline 1 & $\begin{array}{c}\text { the observation } \\
\text { items }\end{array}$ & 0.946 & 0.943 & 0.895 \\
\hline
\end{tabular}

Source: the observation tool collected from the research sample.

\section{Data analysis:}

Reliability test: This technique compares the average grades of the social workers before and after, following completion of the intervention program, and tracks the changes based on the same balance for distributing the test grades. It is known as the terminals comparison as it is based on the strong terminal, which we call strong balance power terminal, and the weak balance power, which we call weak balance power terminal, mean social workers who get high grades in the application after the interventions or in the following test, have a strong balance power terminal and vice versa (Morsi, 2013, p.83-86).

Analysis of variance (ANOVA) or Fisher test (F-test) was used for comparison of a one-way ANOVA used for comparison between more than two means:

\begin{tabular}{|c|c|c|c|c|c|}
\hline $\begin{array}{l}\text { Variance } \\
\text { Sources }\end{array}$ & $\begin{array}{c}\text { Sum } \\
\text { Square }\end{array}$ & $\begin{array}{l}\text { Degree } \\
\text { of free }\end{array}$ & $\begin{array}{c}\text { Mean of sum } \\
\text { square }\end{array}$ & \multicolumn{2}{|c|}{ F. ratio } \\
\hline $\begin{array}{c}\text { Between } \\
\text { groups } \\
\text { (Regression) }\end{array}$ & $\begin{array}{l}\text { RSS or } \\
\text { BSS }\end{array}$ & k-1 & $\begin{array}{c}\mathrm{MSR}=\mathrm{SSR} / \mathrm{k}- \\
1\end{array}$ & MSR & BMS \\
\hline $\begin{array}{l}\text { Within } \\
\text { groups } \\
\text { (Error) }\end{array}$ & $\begin{array}{l}\text { ESS or } \\
\text { WSS }\end{array}$ & $n-k$ & $\begin{array}{c}\mathrm{MSE}=\mathrm{SSE} / \mathrm{n}- \\
\mathrm{k}\end{array}$ & MSE & WMS \\
\hline Total & TSS & $n-1$ & & & \\
\hline
\end{tabular}

1- Chi Squared test: Is any statistical hypothesis test where in the sapling distribution of the test statistic a chi-squared distribution when the null hypothesis is true.

2- Kruskal-Wallis: This non-parametric test was used to test two independent samples or more, or the same sample in different times. This test was utilized to measure the impact of a particular training program. The data used in this analysis are ordinal ranks (Dominic Salvatore, 1984, pp. 151-160). 


\section{The Egyptian Journal of Social Work (EJSW) www.ejsw.org \\ ISSN: 2356-9204

3. Trend Equations: The equation below represents the relationship between time and changes in the first component, that is, it shows the growth in the improvement of the first component.

$$
\begin{array}{cc}
Y=e^{33.19+0.24 t} & F=507.2 \\
R^{2}=\mathbf{0 . 9 0 7} &
\end{array}
$$

Time, as an independent factor, involves other factors such as increasing knowledge, information and experience which can produce growth in the improvement of components items, (evident when measured in the period before, the period after, and in the following period, assuming each period was 4 months).

Every 4 months, a growth in the degree of improvement will occur by $24 \%$ of the total score, with $90.7 \%$ of this change being due to the time factor. This equation is statistically significant at the probability level of 0.01 .

The equation below represents the relationship between time and changes in the second component, that is, it shows the growth in the improvement of the second component.

$$
\begin{array}{lll}
Y=e^{43.88+0.213 t} & F=454.1 & R^{2}=0.897
\end{array}
$$

The increase in time by one period (4 months) shows an increase in the improvement rate of $21.3 \%$ of the total score, with $89.7 \%$ of this change being due to the time factor. This equation is statistically significant at the probability level of 0.01 .

The equation below represents the relationship between time and changes in the third component; it shows the growth in the improvement of the third component.

$$
\begin{array}{lll}
Y=e^{37.32+0.209 t} & F=495.7 & R^{2}=0.905
\end{array}
$$

The increase in time by one period (4 months) will result in an increase in the degree of improvement of $20.9 \%$ of the total score, with $90.5 \%$ of this change being due to the time factor. This equation is statistically significant at the probability level 0.01 .

The equation below represents the relationship between time and the first component, that is, it shows the growth in the improvement of the elderly

$$
\mathbf{Y}=\mathrm{e}^{39.52+0.209 t} \quad \mathbf{F}=\mathbf{2 7 8 . 1 5} \quad \mathbf{R}^{2}=
$$

0.801

The increase in time by one period (4 months) will show an increase in the degree of improvement of $20.9 \%$ of the total score, with $80.1 \%$ of this change being due to the time factor. This equation is statistically significant at the probability level of 0.01 . 


\section{The Egyptian Journal of Social Work (EJSW) www.ejsw.org \\ ISSN: 2356-9204 Vol 1, No.5, January 2018}

This confirms the success of the experiment and the training program, having a positive influence on the trainees, and making it possible to measure its impact on the elderly. (Morsi, 2013, p.83-86).

\section{Results}

1. The findings of the experiment yielded positive results related from the group work training program to develop social workers' knowledge of creative methods in maintaining elderly people's life quality. The analysis as shown in table no.3 resulted in significant changes of statistical proof at the probability level of 0.01 and 0.05 .

2. There was a positive result shown in using the group work training program to develop social workers' awareness around older age and maintenance of elderly people's life quality. Table no.3 demonstrated results which showed significant changes at the probability level of 0.01 and 0.05 .

3. There was a positive result shown in using the group work training program to develop social workers' knowledge of creative methods used to maintain elderly people's life quality. Table no.4 shows significant changes at the probability level of 0.01 and 0.05 .

4. There was a positive result shown in using the group work training program to support social workers in using creative methods to maintain elderly people's life quality. Table no.5 showed significant changes at the probability level of 0.01 and 0.05 .

5. Analysis of table no.6 showed significant differences between the observations of the elderly group before, after and following the intervention with the social workers at the elderly care home. Observations of the elderly people yielded significant findings at the probability level 0.01 and 0.05 for all sentences.

The tables were displayed in light of the more important results which show the changes arranged by the items which incurred more than a $90 \%$ change, less than $90 \%$ to $70 \%$ change, less than $70 \%$ to $50 \%$ change and the items which have incurred less than a $50 \%$ change (the researcher did not display all the items in each component but mentioned the more important results according to the Previous Categories).

(The findings section does not discuss the implications of the findings. That is included in the discussion section of the paper). Without a control group or random assignment, the validity of the results are compromised. 


\section{\begin{tabular}{||lr||}
\hline \hline The Egyptian Journal of Social Work (EJSW) & www.ejsw.org \\
ISSN: 2356-9204 & Vol 1, No.5, January 2018 \\
\hline
\end{tabular}}

\section{Discussion:}

The researcher can organize the discussion according to the study's goals:

The research was conducted by (Michelle Rickett and Miriam Bernard, 2014). The reviewed evidence highlights the benefits of older people's drama participation, particularly in terms of health and well-being, improved group relationships, and opportunities for learning, creativity, being challenged and taking risks. It also illustrates the power of dramatic engagement to encourage empathy, reflection and transformed views of the self and others. This is of value to older participants, to other groups involved in drama projects (care givers, health and social care professionals, families). This research confirmed the result's current study. Which discuss the social worker's awareness, and the importance of increasing the social workers' knowledge with regard all about the elderly agreed with the learning theory, which is a guide theory at the current study.

The percentage change in the first component in the social workers' measurement to develop their awareness around older age, are the items which have changed percentages according to the categories, which have changed more than 90\% (4 items), and the others which have changed from $70 \%$ to less than $90 \%$ (3 items), the change of less than $70 \%$ to $50 \%$ occurred in 3 items, finally, the lowest change of $50 \%$ occurred in 3 items (see table No.3). This is confirmed with the study (Magid Taheri, Mehri Mohammadi, Babak Paknia and Abolfazl Mohammadbeigi, 2013). Lifestyle choices are associated with cardiovascular disease and mortality. Iran started to experience population ageing, it was important to consider and address elderly people's needs and concerns, which might have direct impacts on their wellbeing and quality of life. This is a cross-sectional study that was conducted in Tehran, Iran. Questionnaire was designed to measure knowledge, attitude and practice about healthy lifestyles. it was completed by 412 elderly people during 2012. The results shown our findings revealed, that the elderly have a low level of knowledge, attitude and performance towards a healthy lifestyle. It seems designing a comprehensive program regarding a healthy lifestyle in this population to be of prime necessity. So, our results suggest measuring the quality of life and general health status in elderly people. 


\section{The Egyptian Journal of Social Work (EJSW) www.eisw.org \\ ISSN: 2356-9204 Vol 1, No.5, January 2018}

The study attempted to verify the effectiveness of the group work training program to develop social workers' knowledge of creative methods in maintaining elderly people's life quality. These findings are confirmed by research done with (Dohmen, Britta Nareikko, Liris, Stromsten \& Minna, 2012), indicated that the elderly clients enjoyed the self-expression activities very much and wished for more programs of this kind of activities, This research has been agreed with the current study in the use of self-expression activities to give self-confidence and feelings of participation in the association, so improve the quality of their lives, consistent with the cognitive theory's literature which is consider as a basic theory, the researcher adopted it in the training program.

A study by (Morag Farquhar, (1995) mentions the definition and measurement of the concept of quality of life, identify individual's views of the quality of their lives and to test the relevance of various scales used to measure quality of life. The study focuses on older people in two contrasting areas of south east England, and demonstrates not only that older people can talk about, and think about, quality of life, but also highlights how quality of life varies for different age groups of the elderly population living at home, in different geographical areas. In addition, early conclusions also indicate that there is more to quality of life than health: indeed, social contacts appear to be as valued components of a good quality of life as health status, this study agreed with the current study in the importance of identify the residents views of the quality of their life, also confirmed that the health is the more needed for maintaining quality life of elderly people. (P 1439)

South Australia department of Health, Statewide Service Strategy Division, (2009), indicated that normal ageing involves physical and mental changes which may impact on sight, hearing, memory, motor sensory skills, mobility and balance. Ageing also brings an increased risk of developing chronic diseases and other agerelated diseases such as cancer. The rate of ageing varies between individuals and is influenced by genes, behaviors and environments. Socioeconomic disadvantage and a range of environmental factors are known to increase the incidence of disease or disability later in life; all influence the meaning of health and wellbeing for older people. The current study confirmed the importance of knowing all the stages of elder age, so the social workers and all the staff who dealing with them able to establish programmes which faced their needs and 


\section{The Egyptian Journal of Social Work (EJSW) www.eisw.org \\ ISSN: 2356-9204 Vol 1, No.5, January 2018}

demands, according to the learning theory whish consider as a guided theory at the current study. (p.3)

The percentage change in the second component in the social workers' measurement to develop their awareness around older age are the items which have changing percentages according to the categories, those which have changed more than 90\% (3 items), and the others which have a changed from $70 \%$ to less than $90 \%$ (5 items), the change occurring in less than $70 \%$ to $50 \%$ (6 items), finally the lowest change of $50 \%$ in (2 items) (see table No.4).

The Irish Association of Social Workers, (2011), identified that the rights of older people are no different from the rights of any other person. There is, however, an increasing risk to the realization of these rights to the extent that physical or mental frailty or disability imposes limitations on some older people. The needs of such older people are for the support and services to counteract the effects of these limitations. Human rights and "quality of life" or "life satisfaction" are clearly related. Any deliberate obstruction to the achievement of a satisfying and productive life represents an invasion of the rights of the individual. Equally, the lack of reasonable support services to counteract the effects of physical or mental disability also represents a threat to the rights of older people. The following is a list of some of the "domains" of quality of life, the threats to these domains and how these can be counteracted: Material Well-Being, Emotional Well-Being, Social Inclusion, Physical Well-Being, Interpersonal Relationships and Self Determination. According to this research the current study seeking for enhancing the social workers' knowledge which consistent with cognitive theory's literature - about the elderly people rights and their needs to provide a well-being life which they deserved; this is confirmed by the first result of the study. (PP 3, 4)

Simeon Brody, (2010) emphasized the knowledge and evidence base for social work practice: Social work has developed its own academic discipline with a knowledge base that draws on psychology, sociology, social policy, law, philosophy, ethics and other subjects as they relate to complex social work tasks. The knowledge base, skills and qualities of social work: through extensive training, social workers can make a vital contribution in situations where there are high levels of uncertainty, stress, conflicts of interest and risk. The current study seeks to train the social workers draws on specialist skills and knowledge to assess situations and to be able to design 


\section{The Egyptian Journal of Social Work (EJSW) www.ejsw.org \\ ISSN: 2356-9204 Vol 1, No.5, January 2018}

programmes according the needs of elderly by using new creative methods to maintain the quality life.

Andrea Gaggioli et al, (2014) mentioned that living in a nursing home might lead to depression, loss of self-efficacy, and loss of trust in personal skills and resources. A group reminiscence program, with a specific path guiding older people to re-evaluate their past life events, has the potential to strengthen the personal value of the institutionalized individual and foster their sense of identity. Listening to others, responding to them, and feeling close to life events of other people could provide a benefit in the quality of life. That is what the current study confirmed that while the elderly live at the elderly homes, they need to communicate with each other and external environment, doing various; activities can provide the natural social life to feel better with the communication, they still able to deal, express about themselves, and reach to the maintaining quality life.

The percentage change in the third component in the social workers' measurement to support them to use creative methods, are the items which have a high changing percentage according to the categories. Those which have changed more than 90\% (3 items), and the others which have changed from $70 \%$ to less than $90 \%$ (3 items), the change that occurred less than $70 \%$ to $50 \%$ was in 3 items, finally the lowest change of $50 \%$ (4 items) (see table No.5). (Social care institute for excellence, 2010), confirmed that social workers have a central role in developing and delivering personalized social care and support services in adult social services produced by key organizations in social work. Social work is focused on supporting independence, and promoting choice and control for people facing difficulties due to effects of age and other circumstances.

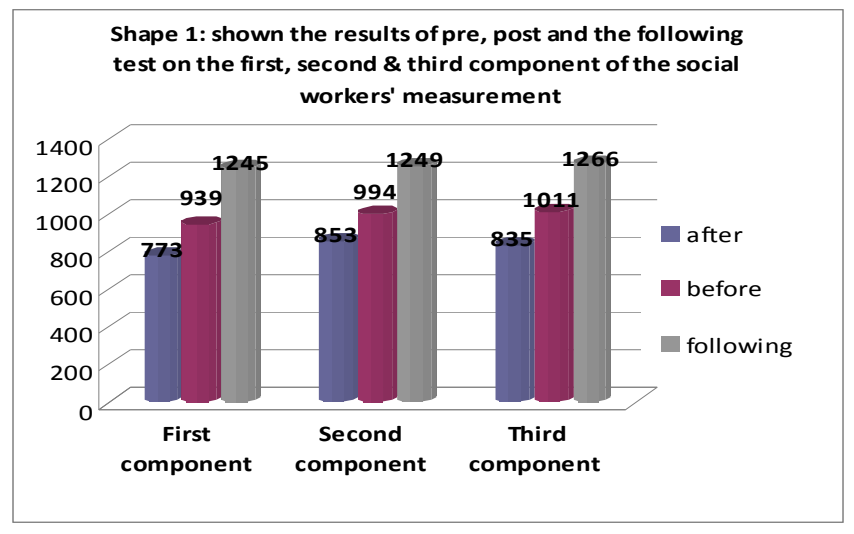




\begin{tabular}{||lr||}
\hline The Egyptian Journal of Social Work (EJSW) & www.ejsw.org \\
ISSN: $2356-9204$ & Vol 1, No.5, January 2018 \\
\hline
\end{tabular}

By analyzing figure no.2, which shows the comparison between pre, post and the following test on the first, second \& third component of the social workers' measurement, the result confirms there is a change in scores (pre-, post- and following test) due to the intervention program which was applied with the social workers.

Social workers' role is to ensure that in striving towards improved health and wellbeing outcomes of older people, useful and appropriate support systems are in place, engaged and utilized to their full extent. This includes assisting older people, and in some cases their families, to make significant life decisions based on the best aged care related information and resources available. Social workers collaborate with the older person in question to ensure personcentered health and wellbeing outcomes are achieved by engaging with appropriate support systems (formal and informal), and evaluating their effectiveness.

Laura Huhtinen-Hildén indicated that creativity and arts activities can be enriching at any phase of a person's life. We need experiences, emotions and possibilities for self-expression also later in life. Arts, arts-based methods and a creative approach can play a significant role in supporting meaningful everyday life in elderly care. Using creativity and arts in elderly care can mean very simple things like humming or sharing memories. Participation in arts activities or seeing a performance can be important sources of enjoyment. That's what the current study goal to use creative methods to enriching the elderly life, and agreed with the learning and communication theory which the researcher depended on it while he trained the social workers at the training program.

Anne-Marie Botek, (2017) mentioned restoring the storytelling role to seniors, While working with seniors in a local nursing home, Botek began to realize that traditional reminiscence exercises weren't having much of an impact on people suffering from dementia. Previous experience had taught her that giving aging adults the freedom to "perform" had a profoundly positive impact on how they experienced the aging process. One of the prime benefits of storytelling is the sense of community building it creates" Botek says. Seniors take turns contributing to the story, which is moderated by the facilitator, who asks open-ended questions and records and repeats participants' responses to keep the flow of the story going, and asking to carry out this method as an activity with elderly participants. That's agreed with the current study to use creative methods with elderly to 


\section{The Egyptian Journal of Social Work (EJSW) www.eisw.org \\ ISSN: 2356-9204 \\ Vol 1, No.5, January 2018}

restore their memories seeking for maintaining quality life according to the communication theory which is a guidance theory at the current study.

While (Annie Crowe, Tereza Crvenkovic, Nives Crvenkovic, 2014, pp.6,7) mentioned that all of us agree that social work in aged care requires a high level of maturity as well as knowledge and skill, it seems to me that it would be sensible to help social workers develop their resilience and ability to take care of themselves so that they can stay working with older people and their families.

The researcher has to point out that the study's results cannot be generalized as they belong to one group pre- post -test design, and findings are indicators of the program's success.

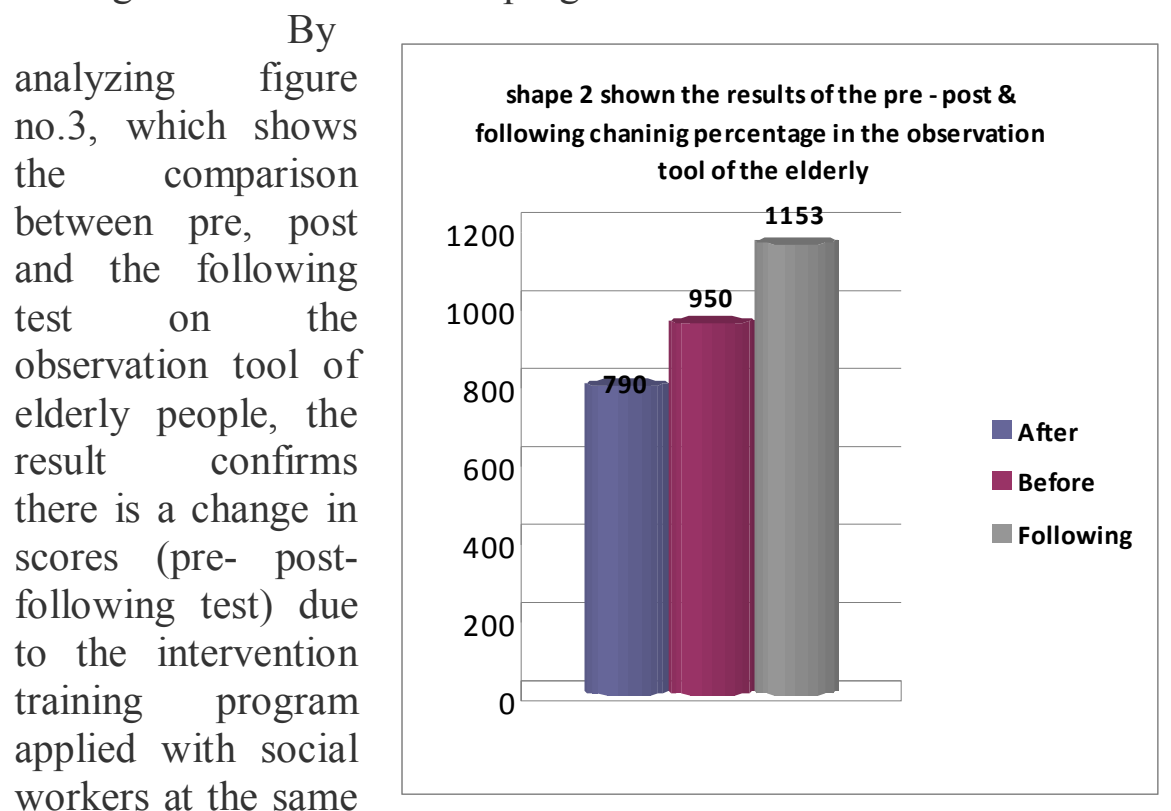

association. The observation's results of some elderly people at the association demonstrated that they have a high response because they had a predisposition in earlier life. (by using the task group with the elderly people at the elderly home) This increased the effectiveness of the application of the intervention program, which prompted the others to imitate them and use innovative creative methods (old fashion / seminars among themselves to restore memories / listen to music and religious radio programs). This is consistent with Abigail Simms's article, 2016 which mentions that creative expression can help connect people, at all stages of life or their recovery from trauma. There are many routes to self-expression. Creativity can be explored 


\begin{tabular}{||lr||}
\hline The Egyptian Journal of Social Work (EJSW) & Www.ejsw.org \\
ISSN: $2356-9204$ & Vol 1, No.5, January 2018 \\
\hline
\end{tabular}

through a variety of artistic disciplines. Commonly identified methods include drama, dance, music, creative writing and the visual arts, including photography. All these activities engage the participant/artist in a process that uses a holistic health framework to access physical, mental, spiritual and social well-being. Creative expression can lead us to a deeper level of understanding and selfdiscovery, the article describes creative expression as "the language that lives in the heart and the spirit. It's the language that emerges when you find the safety to really listen to your heart.

\section{Limitations:}

The researcher has to point out that the study's results cannot be generalized as they belong to one group pre- post-test design,. The findings are indicators of the program's success while there are some Challenges occurred during the program's implementation included the absence of 3 social workers in the third group meeting. This issue was solved by asking the social workers who attended the meeting to inform them about the knowledge that they missed. In addition, one of the residents passed away, that solved by analyzing the data for 23 elderly people not 24 . Also, the researcher faced decreased and nonexistent in tools at the association to apply the creative methods; this solved by providing the tools and possibilities through the researcher. The results were compared to the main study's problem which is train the social workers to use creative methods for maintain the elderly quality life in the elderly home, considering to the improvement or decrease as an indicator which is a judge to the program' success instead of using the control group. Therefore, none of the social workers were excluded to achieve the public benefit.

\section{Implications for Future Study:}

The author confirmed to the importance of conducting studies in group work and in social work to modernize the methods used in elderly care homes, through implementing and activating the role of social workers in elderly care homes and training them in the use of the creative methods which are mentioned in the research depending on the learning, communication, cognitive theory, and group task in group work practice, to maintain the elderly life quality. 


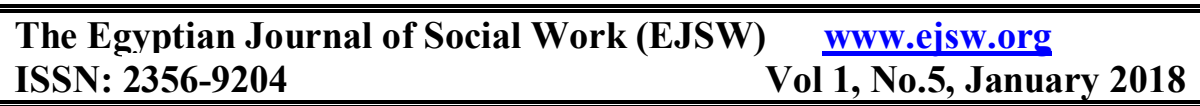

\section{REFERENCES}

Abigail Simms,(2016) Creative Expression, originally published in $\underline{\text { Reunion Issue } 3}$, Joyful heart Foundation, .Retrieved from http://www.joyfulheartfoundation.org/reunion/creative-expression.

Andrea Gaggioli, et al. (2014). Effectiveness of group reminiscence for improving wellbeing of institutionalized elderly adults: study protocol for a randomized controlled trial, US National Library of Medicine. National Institutes of Health,doi: 10.1186/1745-6215-15-408. Retrieved from

https://www.ncbi.nlm.nih.gov

Anne-Marie Botek,(2017). When a Senior Can't Remember the Story, Let Them Make It Up, ageing care.com, Retrieved from https://www.agingcare.com.

Annie Crowe, Tereza Crvenkovic, Nives Crvenkovic (2013).Social work in aged care, being resilient in challenging and rewarding filed, swift, newsletter of the new branch of AASW, SPRING 2013. Retrieved from

https://www.google.com.eg/url?\%2Fdocument $\% 2$ Fitem\%2F4900\&us $\mathrm{g}=\mathrm{AFQjCNHWH7Msu5IA}$ 4ZqtXc3khgNYKUxWw

Australian Association of Social Workers (2015, December). Scope of Social Work Practice, Social Work in Aged Care, Melbourne. $\quad$ Retrieved from https://www.google.com.eg/url?Fdocument $\% 2$ Fitem $\% 2 F 8305$ \&usg=AFQjCNFtlHFHfcNhWh4SIRT3WknXtuPiOg.

David Banister, Ann Bowling, (2004, April). Quality of life for the elderly: the transport component, Volume 11, Issue 2, Retrieve from

http://www.sciencedirect.com/science/article/pii/S0967070X0 $\underline{3000520}$

Dohmen, Britta Nareikko, Liris, Stromsten\& Minna, (2010) Selfexpression and creative activities with elderly clients in caring TV, Laurea University of Applied Sciences , Active Life Village, Retrieved from

https://www.google.com.eg/search?Selfexpression+and+creative+acti vities

Dominic Salvatore, (1984) Statistics and economics, macrohaill, AlAhram library press. 


\begin{tabular}{|l|r|}
\hline The Egyptian Journal of Social Work (EJSW) & www.eisw.org \\
ISSN: 2356-9204 & Vol 1, No.5, January 2018 \\
\hline
\end{tabular}

George S Getzel,(2008) Poetry Writing Groups and the Elderly, A Reconsideration of Art and Social Group Work, Journal of Social Work with Groups, Volume 6, Issue 1,. Retrieved from http://www.tandfonline.com/doi/abs/10.1300/J009v06n01 07

Gopalakrishnan Netuveli,David Blane,(2008), Quality of life in older ages, $\mathrm{Br}$ Med Bull , Retrieved from https://academic.oup.com

Heba Mohamed Tawfik, (2012), Alzheimer 's Journal January 201204-10 The Egyptian Society for the care of Alzheimer' $s$ patients (brain failure) and their families. Retrieved from

Http://www.tabibnafsany.com/alzahiemar_activities_for_pts.html

K. L. Haywood Email,(2005, September) A. M. Garratt, R. Fitzpatrick,( 2005) Quality of life in older people: A structured review of generic self-assessed health instruments, , Volume 14, Issue 7, Retrieved from https://link.springer.com

Karen la Cour,( 2009), Creating connections to life during lifethreatening illness: Creative activity experienced by elderly people and occupational therapists, Journal Scandinavian Journal of Occupational Therapy Volume 12, Issue 3. Retrieved from

http://www.tandfonline.com/doi/abs/10.1080/11038120510030889

Laura Huhtinen-Hildén, Bringing creativity, arts and arts-based approaches to elderly care. Retrieved from https://www.helsinkismart.fi

Magid Taheri, Mehri Mohammadi, Babak Paknia and Abolfazl Mohammadbeigi,(2013, September) Elderly awareness on healthy lifestyle during aging, ISSN: 2329-9088, Tropical Medicine \& Surgery, P.1, doi: 10.4172/2329-9088.1000139. Retrieved from https://www.omicsonline.org

Michelle Rickett and Miriam Bernard,( 2014) Aging, drama and creativity, Keele University, Retrieved from http://gtr.rcuk.ac.uk

MoragFarquhar, (1995, November), Elderly people's definitions of quality of life, Social Science \& Medicine, Volume 41, Issue 10, Pages 1439-1446. Retrieved from https://doi.org/10.1016/0277-9536(95)00117-P

Morsi.(2013). Social Statistics, Alexandria, the modern university Office press 


\begin{tabular}{|l|r|}
\hline The Egyptian Journal of Social Work (EJSW) & www.eisw.org \\
ISSN: 2356-9204 & Vol 1, No.5, January 2018 \\
\hline
\end{tabular}

Personalization for social workers in adults' services, (2010, October) Personalisation briefing: implications for social workers in adults' services, Social care institute for excellence, Retrieved from http://www.scie.org.uk

Simeon Brody, What is the role of social workers?, (2010, September 20) in Students. Retrieved from http://www.communitycare.co.uk.

South Australia. Dept. of Health. Statewide Service Strategy Division,( 2009, May) Health Service Framework for Older People, Improving Health and Wellbeing Together. Retrieved from http://www.sahealth.sa.gov.au

The Central Agency for Mobilization and Statistics,(2015). Retrieved from http://www.gafrd.org/links/27614.

The Central Agency for Mobilization and Statistics , (2016). Retrieved from http://www.capmas.gov.eg

The Irish Association of Social Workers, The Role of the Social Worker with Older Persons, IASW) Special Interest Group on Ageing (SIGA), August 2011. Retrieved from https://www.google.com.eg

UN and Aging. Retrieved from

http://www.un.org/arabic/esa/ageing/medicaltreatment.html

Yaretzky A, Levinson M, Kimchi OL, (1996) Clay as a therapeutic tool in group processing with the elderly, American Journal of art Therapy, Retrieved from http://europepmc.org 


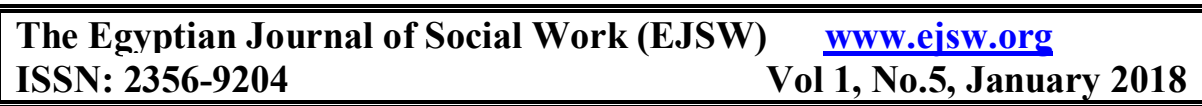

\section{Reviewers Comments}

In this section, we describe the common important comments of the reviewers in the previous articles. These comments help authors in the future to avoid these basic mistakes when they prepare their articles. Some of these comments are:

1) There multiple problems with the English language.

2) Authors must summarize Literature review in more depth.

3) The authors must give most attention to the reliability and validity of research instruments.

4) The research finding or results must be clearly presented.

5) Social work researcher is not only quantitative researcher, but also he/she interest in qualitative comments about statistic analyses.

6) In experimental researches the sample must be suffusion and lead to valid results

7) There is no indication the researcher obtained informed consent from the client or the parents for the client to participate in this study.

8) No information provided on the demographics of the participants or comparisons of the participants in the treatment and control groups

9) The discussion is entirely unsupported and largely unrelated to the specific findings of the study. If the authors have difficult in getting a large enough he need to talk about these difficulties

10) Discussion of how findings could be implemented could be expanded

11) Expand discussion of how findings could be implemented in social work practice and education

12) The researcher must choose appropriate statistic processes to his hypothesis.

13) The article should have more of a "Discussion" section that does not simply describe the data but also identifies the implications of the study for revised theory or practice. In this section the authors should also identify limitations of the study 